Article

\title{
Bioactive Cembranoids from the Dongsha Atoll Soft Coral Sarcophyton crassocaule
}

\author{
Wan-Yu Lin ${ }^{1}$, Yi Lu ${ }^{1}$, Jui-Hsin Su ${ }^{2,3}$, Zhi-Hong Wen ${ }^{1}$, Chang-Feng Dai ${ }^{4}$, Yao-Haur Kuo ${ }^{5}$ and \\ Jyh-Horng Sheu ${ }^{1,6}, *$
}

1 Department of Marine Biotechnology and Resources, National Sun Yat-sen University, Kaohsiung 804, Taiwan; E-Mails: lemotylin@gmail.com (W.-Y.L.); snakefoot5052@gmail.com (Y.L.); wzh@mail.nsysu.edu.tw (Z.-H.W.)

2 National Museum of Marine Biology \& Aquarium, Pingtung 944, Taiwan;

E-Mail: x2219@nmmba.gov.tw

3 Graduate Institute of Marine Biotechnology, National Dong Hwa University, Pingtung 944, Taiwan

4 Institute of Oceanography, National Taiwan University, Taipei 112, Taiwan;

E-Mail: corallab@ntu.edu.tw

5 National Research Institute of Chinese Medicine, Taipei 112, Taiwan;

E-Mail: kuoyh@nricm.edu.tw

6 Division of Marine Biotechnology, Asia-Pacific Ocean Research Center, National Sun Yat-sen University, Kaohsiung 804, Taiwan

* Author to whom correspondence should be addressed; E-Mail: sheu@ mail.nsysu.edu.tw;

Tel.: +886-7-5252000 (ext. 5030); Fax: +886-7-5255020.

Received: 25 April 2011; in revised form: 26 May 2011 / Accepted: 30 May 2011 /

Published: 9 June 2011

\begin{abstract}
Seven new cembranoids, sarcocrassocolides F-L (1-7), have been isolated from a soft coral Sarcophyton crassocaule. Their structures were determined by extensive spectroscopic analysis. Most new compounds exhibited significant cytotoxic activity against a limited panel of cancer cell lines, and the structure-activity relationship was studied. Compounds 1-7 were found to display significant in vitro anti-inflammatory activity in LPS-stimulated RAW264.7 macrophage cells by inhibiting the expression of the iNOS protein. Compound 4 was also found to effectively reduce the level of COX-2 protein.
\end{abstract}

Keywords: soft coral; Sarcophyton crassocaule; cytotoxic activity; anti-inflammatory activity 


\section{Introduction}

The cembrane-type compounds have been found to be the most important diterpenoidal constituents in marine coelenterates [1-8]. In the investigation of the bioactive metabolites from soft corals of Taiwanese waters, many bioactive cembranoids have been isolated from octocorals (Alcyonaceae) belonging to the genera Sinularia [9-15], Lobophytum [16,17], Sarcophyton [18-21] and Pachyclavularia [22,23]. Some of these metabolites have been shown to exhibit cytotoxic activity against the growth of various cancer cell lines [9,11,13,17-23], and/or anti-inflammatory activity [10-12,14-17]. Our recent study of the chemical constituents of the Dongsha Atoll soft coral S. crassocaule [24] has yielded cembranoids sarcocrassocolides A-E, which exhibited cytotoxic and anti-inflammatory activities. Our continuing chemical investigation of the dame collection of this organism, with the aim of discovering further biologically active natural products, again led to the isolation of seven new cembranoids, sarcrocrassocolides F-L (1-7) (Chart 1). The structures of 1-7 were established by extensive spectroscopic analysis, including careful examination of 2D NMR $\left({ }^{1} \mathrm{H}-{ }^{1} \mathrm{H}\right.$ COSY, HMQC, HMBC and NOESY) correlations. The cytotoxicity of compounds 1-7 against human breast adenocarcinoma (MCF-7), human colon adenocarcinoma (WiDr), human laryngeal carcinoma (HEp-2) and human medulloblastoma (Daoy) cell lines was studied, and the ability of 1-7 to inhibit the up-regulation of pro-inflammatory iNOS (inducible nitric oxide synthase) and COX-2 (cyclooxygenase-2) proteins in LPS (lipopolysaccharide)-stimulated RAW264.7 macrophage cells was also examined.

Chart 1. Structures of Metabolites 1-7.

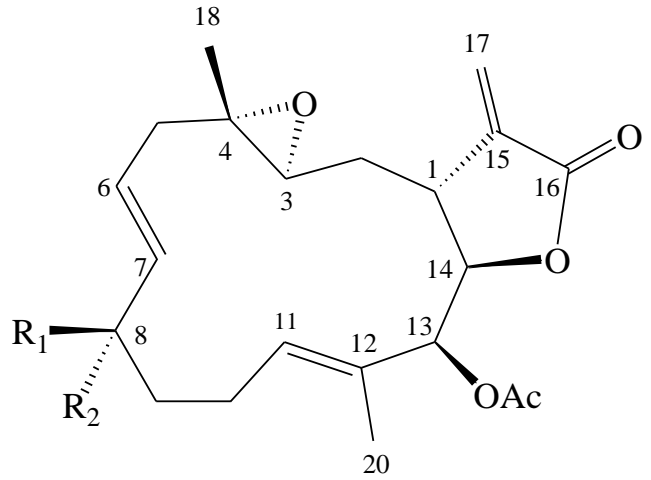

1: $\mathrm{R}_{1}=\mathrm{CH}_{3} \quad \mathrm{R}_{2}=\mathrm{OOH}$

2: $\mathrm{R}_{1}=\mathrm{OOH} \mathrm{R}=\mathrm{CH}_{3}$

3: $\mathrm{R}_{1}=\mathrm{CH}_{3} \quad \mathrm{R}_{2}=\mathrm{OH}$

4: $\mathrm{R}_{1}=\mathrm{OH} \quad \mathrm{R}_{2}=\mathrm{CH}_{3}$

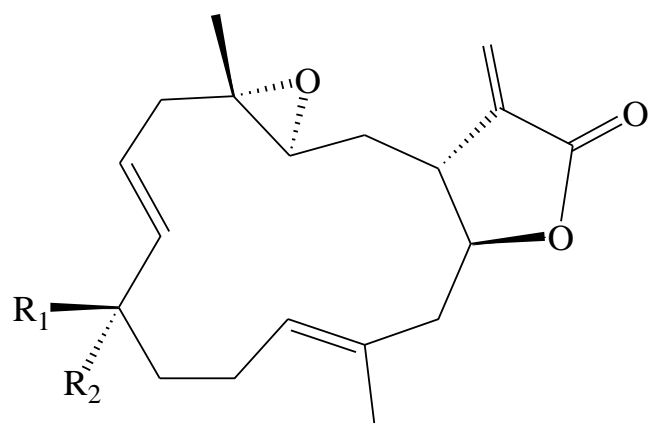

5: $\mathrm{R}_{1}=\mathrm{CH}_{3} \quad \mathrm{R}_{2}=\mathrm{OOH}$

6: $\mathrm{R}_{1}=\mathrm{CH}_{3} \quad \mathrm{R}_{2}=\mathrm{OH}$

7: $\mathrm{R}_{1}=\mathrm{OH} \quad \mathrm{R}_{2}=\mathrm{CH}_{3}$

\section{Results and Discussion}

The HRESIMS $\left(\mathrm{m} / \mathrm{z} 429.1887[\mathrm{M}+\mathrm{Na}]^{+}\right)$of sarcrocrassocolide $\mathrm{F}(\mathbf{1})$ established the molecular formula $\mathrm{C}_{22} \mathrm{H}_{30} \mathrm{O}_{7}$, appropriate for eight degrees of unsaturation, and the IR spectrum revealed the presence of lactonic carbonyl $\left(1757 \mathrm{~cm}^{-1}\right)$ group. The ${ }^{13} \mathrm{C}$ NMR and DEPT (Table 1) spectroscopic data showed signals of four methyls (including one acetate methyl), four $\mathrm{sp}^{3}$ methylenes, one $\mathrm{sp}^{2}$ methylenes, four $\mathrm{sp}^{3}$ methines (including three oxymethines), three $\mathrm{sp}^{2}$ methines, two $\mathrm{sp}^{3}$ and four $\mathrm{sp}^{2}$ quaternary carbons (including two ester carbonyls). The NMR signals (Tables 1 and 2) observed at 
$\delta_{\mathrm{C}} 169.3(\mathrm{qC}), 139.3(\mathrm{qC}), 121.1\left(\mathrm{CH}_{2}\right), 81.1(\mathrm{CH})$, and $37.7(\mathrm{CH})$, and $\delta_{\mathrm{H}} 6.30,5.64$ (each, $1 \mathrm{H}, \mathrm{d}$, $J=2.5 \mathrm{~Hz}), 4.62(1 \mathrm{H}, \mathrm{t}, J=3.0 \mathrm{~Hz})$, and $3.10(1 \mathrm{H}, \mathrm{dt}, J=12.0,2.5 \mathrm{~Hz})$ showed the presence of an $\alpha$-methylene- $\gamma$-lactonic group by comparing the very similar NMR data of the cembranoids with the same five-membered lactone ring [18,19,24]. Signals resonating at $\delta_{\mathrm{C}} 59.1(\mathrm{qC}), 59.2(\mathrm{CH})$ and $\delta_{\mathrm{H}} 2.57(1 \mathrm{H}, \mathrm{dd}, J=6.5,4.5 \mathrm{~Hz})$ revealed the presence of a trisubstituted epoxide. The NMR signals at $\delta_{\mathrm{C}} 84.4(\mathrm{qC})$ and $\delta_{\mathrm{H}} 7.42(1 \mathrm{H}$, brs) showed the presence of a hydroperoxy group at a methine carbon. One trisubstituted and one 1,2-disubstituted double bonds were also identified from NMR signals appearing at $\delta_{\mathrm{C}} 128.7(\mathrm{qC}), 128.7(\mathrm{CH})$, and $\delta_{\mathrm{H}} 5.28(1 \mathrm{H}, \mathrm{dd}, J=7.0,1.0 \mathrm{~Hz})$, and at $\delta_{\mathrm{C}} 124.7(\mathrm{CH})$, $136.4(\mathrm{CH})$, and $\delta_{\mathrm{H}} 5.49(1 \mathrm{H}, \mathrm{dt}, J=16.0,7.5 \mathrm{~Hz})$ and $5.59(1 \mathrm{H}, \mathrm{d}, J=16.0 \mathrm{~Hz})$, respectively. In the ${ }^{1} \mathrm{H}-{ }^{1} \mathrm{H}$ COSY spectrum, it was possible to identify three different structural units, which were assembled with the assistance of an HMBC experiment. Key HMBC correlations of $\mathrm{H}_{3}-18$ to C-3, C-4 and $\mathrm{C}-5 ; \mathrm{H}_{3}-19$ to $\mathrm{C}-7, \mathrm{C}-8$ and $\mathrm{C}-9 ; \mathrm{H}_{3}-20$ to $\mathrm{C}-11, \mathrm{C}-12$ and $\mathrm{C}-13$ and $\mathrm{H}_{2}-17$ to $\mathrm{C}-1, \mathrm{C}-15$ and $\mathrm{C}-16$ permitted the establishment of the carbon skeleton (Figure 1). Furthermore, the acetoxy group positioned at $\mathrm{C}-13$ was confirmed from the $\mathrm{HMBC}$ correlations of methyl protons of an acetate $\left(\delta_{\mathrm{H}} 2.02\right)$ to the ester carbonyl carbon at $\delta_{\mathrm{C}} 169.1(\mathrm{qC})$ and the oxymethine carbon at $77.1(\mathrm{C}-13, \mathrm{CH})$. The $J$ values for both H-6 and H-7 $(16.0 \mathrm{~Hz})$ further confirmed the presence of a trans 1,2-disubstituted double bond at C-6 and C-7. On the basis of the above analysis, the planar structure of $\mathbf{1}$ was established unambiguously.

Table 1. ${ }^{13} \mathrm{C}$ NMR data for compounds $\mathbf{1}-\mathbf{7}$.

\begin{tabular}{|c|c|c|c|c|c|c|c|}
\hline & $1^{a}$ & $2^{b}$ & $3^{b}$ & $4^{b}$ & $5^{a}$ & $6^{a}$ & $7^{a}$ \\
\hline 1 & $37.7, \mathrm{CH}^{c}$ & $38.7, \mathrm{CH}$ & $38.2, \mathrm{CH}$ & $38.2, \mathrm{CH}$ & $41.7, \mathrm{CH}$ & $41.6, \mathrm{CH}$ & $41.4, \mathrm{CH}$ \\
\hline 2 & $35.2, \mathrm{CH}_{2}$ & $35.2, \mathrm{CH}_{2}$ & $36.0, \mathrm{CH}_{2}$ & $34.5, \mathrm{CH}_{2}$ & $32.9, \mathrm{CH}_{2}$ & $32.9, \mathrm{CH}_{2}$ & $32.3, \mathrm{CH}_{2}$ \\
\hline 3 & $59.2, \mathrm{CH}$ & $58.7, \mathrm{CH}$ & $59.2, \mathrm{CH}$ & $59.1, \mathrm{CH}$ & $59.6, \mathrm{CH}$ & $59.1, \mathrm{CH}$ & $59.4, \mathrm{CH}$ \\
\hline 4 & $59.1, \mathrm{qC}$ & $59.0, \mathrm{qC}$ & $59.4, \mathrm{qC}$ & $59.5, \mathrm{qC}$ & $60.2, \mathrm{qC}$ & $60.1, \mathrm{qC}$ & $60.5, \mathrm{qC}$ \\
\hline 5 & $38.6, \mathrm{CH}_{2}$ & $38.6, \mathrm{CH}_{2}$ & $39.2, \mathrm{CH}_{2}$ & $38.8, \mathrm{CH}_{2}$ & $40.1, \mathrm{CH}_{2}$ & $39.8, \mathrm{CH}_{2}$ & $39.8, \mathrm{CH}_{2}$ \\
\hline 6 & $124.7, \mathrm{CH}$ & $125.0, \mathrm{CH}$ & $121.2, \mathrm{CH}$ & $121.5, \mathrm{CH}$ & $125.7, \mathrm{CH}$ & $121.8, \mathrm{CH}$ & $121.0, \mathrm{CH}$ \\
\hline 7 & $136.4, \mathrm{CH}$ & $136.9, \mathrm{CH}$ & $138.9, \mathrm{CH}$ & $140.7, \mathrm{CH}$ & $136.1, \mathrm{CH}$ & $140.1, \mathrm{CH}$ & $140.9, \mathrm{CH}$ \\
\hline 8 & $84.4, \mathrm{qC}$ & $85.2, \mathrm{qC}$ & 72.9, qC & 73.1, qC & $84.9, \mathrm{qC}$ & 73.0, qC & 73.0, qC \\
\hline 9 & $38.7, \mathrm{CH}_{2}$ & $37.1, \mathrm{CH}_{2}$ & $42.3, \mathrm{CH}_{2}$ & $42.0, \mathrm{CH}_{2}$ & $37.7, \mathrm{CH}_{2}$ & $44.6, \mathrm{CH}_{2}$ & $41.6, \mathrm{CH}_{2}$ \\
\hline 10 & $22.0, \mathrm{CH}_{2}$ & $21.4, \mathrm{CH}_{2}$ & $22.0, \mathrm{CH}_{2}$ & $21.8, \mathrm{CH}_{2}$ & 21.7, $\mathrm{CH}_{2}$ & $22.1, \mathrm{CH}_{2}$ & $22.2, \mathrm{CH}_{2}$ \\
\hline 11 & $128.7, \mathrm{CH}$ & $128.3, \mathrm{CH}$ & $128.1, \mathrm{CH}$ & $130.1, \mathrm{CH}$ & $130.6, \mathrm{CH}$ & 131.1, CH & $130.5, \mathrm{CH}$ \\
\hline 12 & $128.7, \mathrm{qC}$ & 129.3, qC & $127.7, \mathrm{qC}$ & 128.6, qC & 129.1, qC & 129.1, qC & 129.2, qC \\
\hline 13 & $77.1, \mathrm{CH}$ & 77.3, CH & $76.4, \mathrm{CH}$ & $77.4, \mathrm{CH}$ & $44.1, \mathrm{CH}_{2}$ & $44.6, \mathrm{CH}_{2}$ & $43.3, \mathrm{CH}_{2}$ \\
\hline 14 & $81.1, \mathrm{CH}$ & $81.4, \mathrm{CH}$ & $81.3, \mathrm{CH}$ & $82.0, \mathrm{CH}$ & $81.3, \mathrm{CH}$ & $82.3, \mathrm{CH}$ & $82.8, \mathrm{CH}$ \\
\hline 15 & 139.3, qC & 139.1, qC & $138.1, \mathrm{qC}$ & 139.0, qC & $139.0, \mathrm{qC}$ & $139.0, \mathrm{qC}$ & 139.1, qC \\
\hline 16 & 169.3, qC & 169.3, qC & $167.4, \mathrm{qC}$ & 169.4, qC & 169.6, qC & $169.6, \mathrm{qC}$ & $169.7, \mathrm{qC}$ \\
\hline 17 & $121.1, \mathrm{CH}_{2}$ & $122.2, \mathrm{CH}_{2}$ & $121.1, \mathrm{CH}_{2}$ & $121.8, \mathrm{CH}_{2}$ & $122.4, \mathrm{CH}_{2}$ & $122.4, \mathrm{CH}_{2}$ & $122.0, \mathrm{CH}_{2}$ \\
\hline 18 & $18.2, \mathrm{CH}_{3}$ & $18.2, \mathrm{CH}_{3}$ & $19.3, \mathrm{CH}_{3}$ & $18.0, \mathrm{CH}_{3}$ & 17.6, $\mathrm{CH}_{3}$ & $17.6, \mathrm{CH}_{3}$ & 17.6, $\mathrm{CH}_{3}$ \\
\hline 19 & 23.5, $\mathrm{CH}_{3}$ & $20.9, \mathrm{CH}_{3}$ & 31.2, $\mathrm{CH}_{3}$ & $28.4, \mathrm{CH}_{3}$ & $22.3, \mathrm{CH}_{3}$ & $29.8, \mathrm{CH}_{3}$ & $29.4, \mathrm{CH}_{3}$ \\
\hline 20 & $15.2, \mathrm{CH}_{3}$ & $15.2, \mathrm{CH}_{3}$ & $16.4, \mathrm{CH}_{3}$ & 14.6, $\mathrm{CH}_{3}$ & 17.0, $\mathrm{CH}_{3}$ & $16.9, \mathrm{CH}_{3}$ & 17.2, $\mathrm{CH}_{3}$ \\
\hline \multirow[t]{2}{*}{ OAc } & $20.8, \mathrm{CH}_{3}$ & $20.8, \mathrm{CH}_{3}$ & $21.8, \mathrm{CH}_{3}$ & $20.8, \mathrm{CH}_{3}$ & & & \\
\hline & $169.1, \mathrm{qC}$ & 169.3, qC & 167.4, qC & 169.3, qC & & & \\
\hline
\end{tabular}

${ }^{a}$ Spectra recorded at $125 \mathrm{MHz}$ in $\mathrm{CDCl}_{3} ;{ }^{b}$ Spectra recorded at $100 \mathrm{MHz}$ in $\mathrm{CDCl}_{3} ;{ }^{c}$ Deduced from DEPT. 
Table 2. ${ }^{1} \mathrm{H}$ NMR data for compounds $\mathbf{1}-\mathbf{4}$.

\begin{tabular}{|c|c|c|c|c|}
\hline & $\mathbf{1}^{a}$ & $2^{b}$ & $3^{b}$ & $4^{b}$ \\
\hline 1 & $3.10 \mathrm{dt}(12.0,2.5)^{c}$ & $3.13 \mathrm{dt}(11.6,2.4)$ & $3.11 \mathrm{dt}(11.6,2.8)$ & $3.04 \mathrm{ddd}(11.2,4.4,2.4)$ \\
\hline \multirow[t]{2}{*}{2} & $1.84 \mathrm{ddd}(14.5,4.5,2.5)^{c}$ & $1.86 \mathrm{~m}$ & $1.82 \mathrm{ddd}(15.2,5.6,2.8)$ & $1.85 \mathrm{~m}$ \\
\hline & $1.69 \mathrm{ddd}(14.5,12.0,7.0)$ & $1.71 \mathrm{~m}$ & $1.72 \mathrm{~m}$ & $1.74 \mathrm{~m}$ \\
\hline 3 & $2.57 \mathrm{dd}(6.5,4.5)$ & $2.58 \mathrm{dd}(6.8,4.8)$ & $2.59 \mathrm{t}(5.6)$ & $2.64 \mathrm{t}(6.4)$ \\
\hline \multirow[t]{2}{*}{5} & $2.48 \mathrm{dd}(14.5,7.5)$ & $2.50 \mathrm{dd}(15.2,6.4)$ & $2.46 \mathrm{t}(2.8)$ & $2.51 \mathrm{dd}(14.4,6.4)$ \\
\hline & $2.27 \mathrm{dd}(14.5,7.5)$ & $2.30 \mathrm{dd}(15.2,6.4)$ & $2.24 \mathrm{t}(2.4)$ & $2.21 \mathrm{dd}(11.6,14.4)$ \\
\hline 6 & $5.49 \mathrm{dt}(16.0,7.5)$ & $5.52 \mathrm{dt}(16.0,6.4)$ & $5.51 \mathrm{~m}$ & $5.51 \mathrm{ddd}(16.0,8.0,6.4)$ \\
\hline 7 & $5.59 \mathrm{~d}(16.0)$ & $5.54 \mathrm{~d}(16.0)$ & $5.49 \mathrm{~m}$ & $5.60 \mathrm{~d}(16.0)$ \\
\hline \multirow[t]{2}{*}{9} & $2.22 \operatorname{ddd}(14.5,10.5,5.0)$ & $1.91 \mathrm{~m}$ & 2.04 brs & $1.87 \mathrm{~m}$ \\
\hline & $1.37 \mathrm{dt}(10.5,5.0)$ & $1.56 \mathrm{~m}$ & $1.45 \mathrm{~m}$ & $1.60 \mathrm{~m}$ \\
\hline \multirow[t]{2}{*}{10} & $2.39 \mathrm{ddt}(17.0,10.5,5.0)$ & $2.04 \mathrm{~m}$ & $2.34 \mathrm{~m}$ & $2.15 \mathrm{~m}$ \\
\hline & $2.02 \mathrm{brs}$ & & $2.05 \mathrm{brs}$ & $2.07 \mathrm{~m}$ \\
\hline 11 & $5.28 \mathrm{dd}(7.0,1.0)$ & $5.30 \mathrm{brs}$ & $5.30 \mathrm{~d}(8.4)$ & $5.41 \mathrm{~m}$ \\
\hline 13 & $5.38 \mathrm{~s}$ & $5.37 \mathrm{~s}$ & $5.38 \mathrm{~s}$ & 5.40 brs \\
\hline 14 & $4.62 \mathrm{t}(3.0)$ & $4.57 \mathrm{t}(2.8)$ & $4.60 \mathrm{t}(2.8)$ & $4.59 \mathrm{dd}(4.4,2.4)$ \\
\hline \multirow[t]{2}{*}{17} & $6.30 \mathrm{~d}(2.5)$ & $6.32 \mathrm{~d}(2.4)$ & $6.31 \mathrm{~d}(2.0)$ & $6.30 \mathrm{~d}(2.4)$ \\
\hline & $5.64 \mathrm{~d}(2.5)$ & $5.67 \mathrm{~d}(2.4)$ & $5.65 \mathrm{~d}(2.0)$ & $5.62 \mathrm{~d}(2.4)$ \\
\hline 18 & $1.30 \mathrm{~s}$ & $1.31 \mathrm{~s}$ & $1.30 \mathrm{~s}$ & $1.32 \mathrm{~s}$ \\
\hline 19 & $1.41 \mathrm{~s}$ & $1.35 \mathrm{~s}$ & $1.34 \mathrm{~s}$ & $1.30 \mathrm{~s}$ \\
\hline 20 & $1.76 \mathrm{~s}$ & $1.73 \mathrm{~s}$ & $1.75 \mathrm{~s}$ & $1.71 \mathrm{~s}$ \\
\hline 8-OOH & $7.42 \mathrm{~s}$ & & & \\
\hline 13-OAc & $2.02 \mathrm{~s}$ & $2.03 \mathrm{~s}$ & $2.02 \mathrm{~s}$ & $2.04 \mathrm{~s}$ \\
\hline
\end{tabular}

${ }^{a}$ Spectra recorded at $500 \mathrm{MHz}$ in $\mathrm{CDCl}_{3} ;{ }^{b}$ Spectra recorded at $400 \mathrm{MHz}$ in $\mathrm{CDCl}_{3} ;{ }^{c} J$ values $(\mathrm{Hz})$ in parentheses.

Figure 1. ${ }^{1} \mathrm{H}-{ }^{1} \mathrm{H}$ COSY and $\mathrm{HMBC}$ correlations for $\mathbf{1 ,} 5$ and $\mathbf{7 .}$
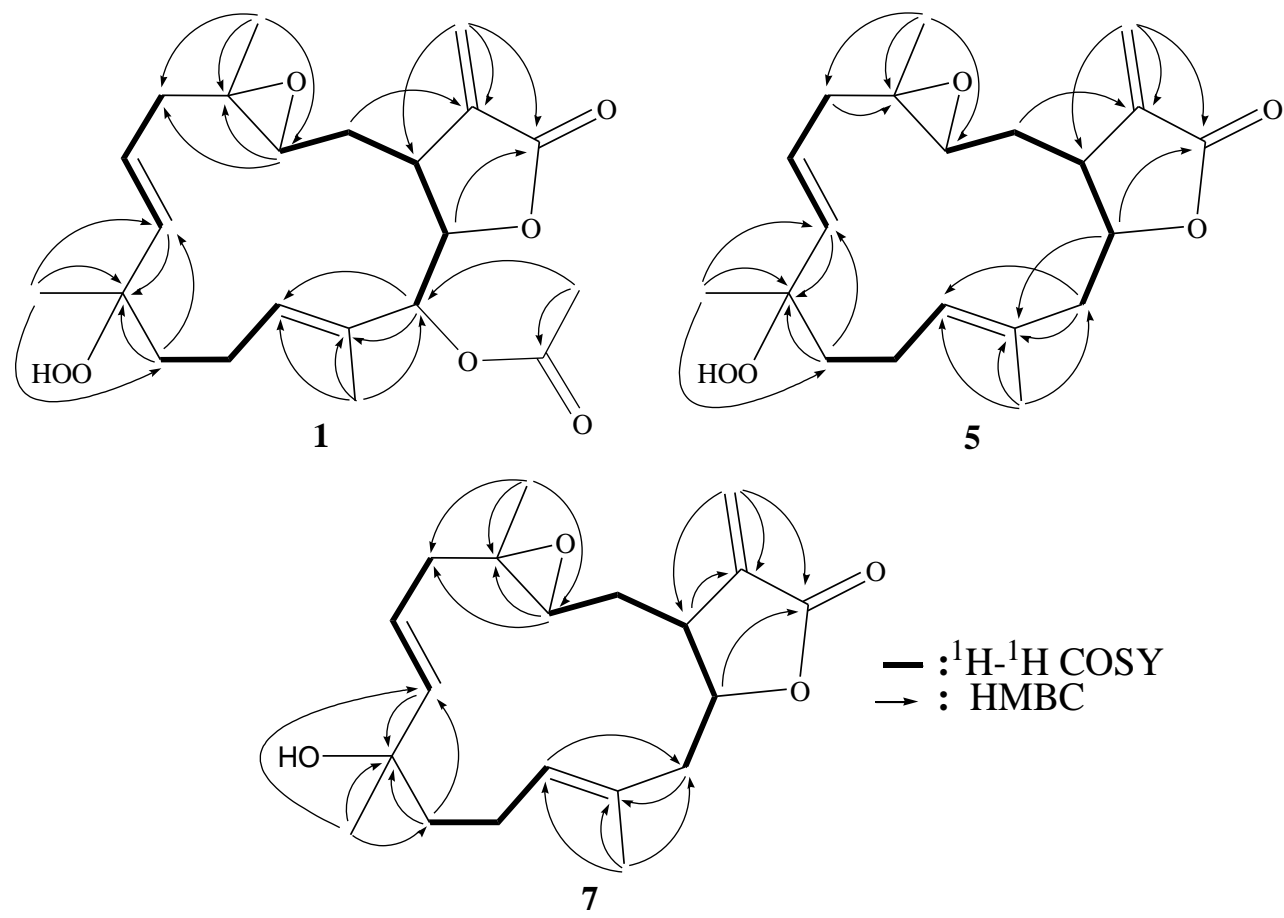
The relative structure of $\mathbf{1}$ was elucidated by the analysis of NOE correlations, as shown in Figure 2. It was found that $\mathrm{H}-1(\delta 3.10, \mathrm{dt}, J=12.0,2.5 \mathrm{~Hz})$ showed NOE interactions with $\mathrm{H}-3(\delta 2.57, \mathrm{dd}, J=6.5,4.5 \mathrm{~Hz})$ and $\mathrm{H}-11(\delta 5.28, \mathrm{dd}, J=7.0,1.0 \mathrm{~Hz}$ ); therefore, assuming an $\beta$-orientation of H-1, H-3 should also be positioned on the $\beta$-face, and the epoxy oxygen should be placed on the $\alpha$-face. NOE correlations of H-3 with H-11 and H-7 $(\delta 5.59, \mathrm{~d}, J=16.0 \mathrm{~Hz})$, but not with $\mathrm{H}_{3}-18(\delta 1.30, \mathrm{~s})$, reflected the trans stereochemistry of epoxide. The $E$ geometry of the trisubstituted double bond at C-11 and C-12 was assigned from NOE correlations of $\mathrm{H}_{3}-20(\delta 1.76$, s) with $\mathrm{H}-10 \alpha$ ( $\delta 2.39$, ddt, $J=17.0,10.5,5.0 \mathrm{~Hz}$ ), and $\mathrm{H}-11$ with $\mathrm{H}-10 \beta(\delta 2.02$, brs), in addition to the upper field chemical shift of C-20 ( $\delta$ 15.2). H-14 $(\delta 4.62, \mathrm{t}, J=3.0 \mathrm{~Hz})$ exhibited NOE correlations with both $\mathrm{H}-13(\delta 5.38, \mathrm{~s})$ and $\mathrm{H}_{3}-20$, but not with $\mathrm{H}-1$ and $\mathrm{H}-11$, indicating the $\alpha$-orientation of both $\mathrm{H}-13$ and $\mathrm{H}-14$. One of the methylene protons at C-9 $(\delta 1.37, \mathrm{dt}, J=10.0,5.0 \mathrm{~Hz})$ exhibited NOE correlations with all of $\mathrm{H}-3, \mathrm{H}-10 \beta, \mathrm{H}-11, \mathrm{H}_{3}-19(1.41, \mathrm{~s})$ and $\mathrm{H}-7$, thus this $\mathrm{C}-9$ proton and $\mathrm{H}_{3}-19$ should be positioned on the $\beta$-face. On the basis of the above findings and detailed examination of other NOE correlations (Figure 2), the relative structure of compound 1 was determined.

Figure 2. Key NOESY correlations for $\mathbf{1}$ and 2.

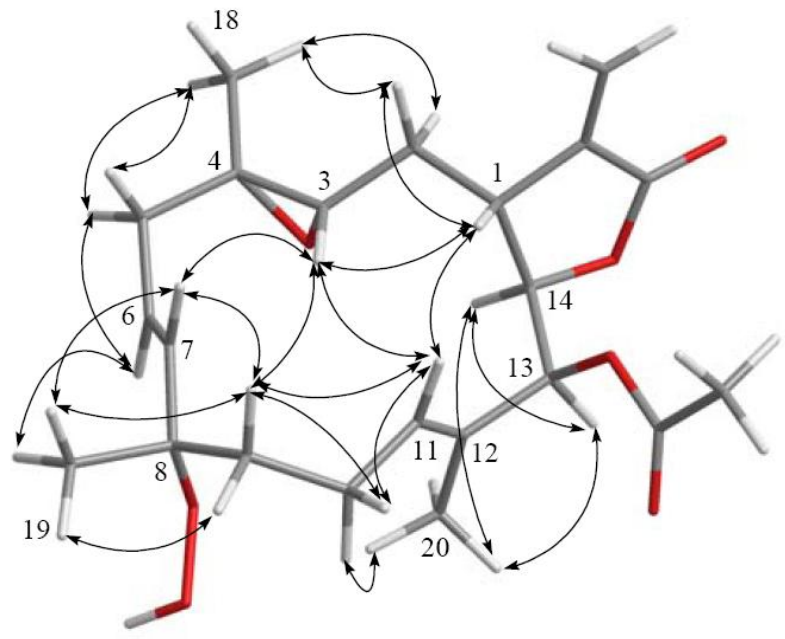

1

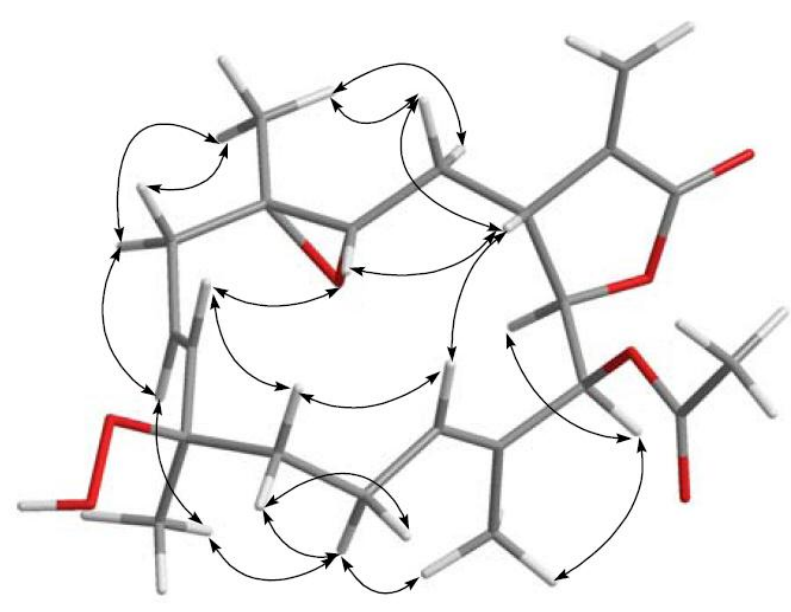

2

Sarcrocrassocolide $\mathrm{G}(2)$ possessed the same molecular formula $\left(\mathrm{C}_{22} \mathrm{H}_{30} \mathrm{O}_{7}\right)$ as that of $\mathbf{1}$, as revealed from HRESIMS. Furthermore, it was found that the NMR spectroscopic data of 2 (Tables 1 and 2) were found to be close to those of $\mathbf{1}$. The overlapping proton signals at $\delta_{\mathrm{H}} 5.52$ and 5.54, measured in $\mathrm{CDCl}_{3}$, was clearly resolved by measuring the ${ }^{1} \mathrm{H}$ NMR spectrum in pyridine- $d_{5}$ (see Experimental Section 3.3.2) into two mutually coupled proton $\left(\delta_{\mathrm{H}} 5.63, \mathrm{dd}, J=16.0,7.0 \mathrm{~Hz}\right.$ and $5.89, \mathrm{~d}, J=16.0 \mathrm{~Hz}$ ), attributable to a trans 1,2-disubstituted double bond. The relative stereochemistry of 2 was determined by analysis of the NOESY spectrum of $\mathbf{1}$, also measured in pyridine- $d_{5}$ (Figure 2). From the NOESY spectrum, it was found that $\mathrm{H}_{3}-19(\delta 1.55$, s) showed NOE interaction with $\mathrm{H}-6(\delta 5.63, \mathrm{dt}, J=16.0$, $7.0 \mathrm{~Hz})$ and $\mathrm{H}-9 \mathrm{a}(\delta 2.06$, ddd, $J=10.0,5.0,3.5 \mathrm{~Hz})$, but not with $\mathrm{H}-7$, showing the $\beta$-orientation of $\mathrm{H}_{3}$-19. Further analysis of other NOE interactions revealed that 2 possessed the same relative configurations at C-1, C-3, C-4, C-13 and C-14, as those of $\mathbf{1}$ (Figure 2). Therefore, 2 was found to be the C-8 epimer of $\mathbf{1}$. 
Sarcrocrassocolide $\mathrm{H} \mathrm{(3)}$ was shown by HRESIMS to possess the molecular formula $\mathrm{C}_{22} \mathrm{H}_{30} \mathrm{O}_{6}$ $\left(m / z 413.1937[\mathrm{M}+\mathrm{Na}]^{+}\right)$. Comparison of the ${ }^{1} \mathrm{H}$ and ${ }^{13} \mathrm{C}$ NMR data (Tables 1 and 2$)$ of compounds 1 and 3 showed that both compounds should have similar structures. C-8 of $\mathbf{3}$ showed signal at upperfield $\delta_{\mathrm{C}} 72.9$ relative to the corresponding signal of $1\left(\delta_{\mathrm{C}} 84.4\right)$, implying the presence of a hydroxyl group at C-8 of $\mathbf{3}$. Moreover, the reduction of $\mathbf{1}$ by triphenylphosphine afforded $\mathbf{3}$. Thus, the structure of $\mathbf{3}$ was established. Sarcrocrassocolide I (4) was shown to possess the same planar structure as that of $\mathbf{3}$ by ${ }^{1} \mathrm{H}-{ }^{1} \mathrm{H}$ COSY and HMBC correlations. In order to confirm the relative stereochemistry of $\mathbf{4}$, a reduction of $\mathbf{2}$ was performed to afford $\mathbf{4}$. Thus, $\mathbf{4}$ was found to be the C-8 epimer of $\mathbf{3}$.

Sarcrocrassocolide $\mathbf{J}(5)$ was shown by HRESIMS to possess the molecular formula $\mathrm{C}_{20} \mathrm{H}_{28} \mathrm{O}_{5}$ $\left(\mathrm{m} / \mathrm{z} 371.1837[\mathrm{M}+\mathrm{Na}]^{+}\right)$. The IR spectrum of $\mathbf{5}$ showed the absorption of lactonic carbonyl $\left(1760 \mathrm{~cm}^{-1}\right)$ group. Comparison of the NMR data (Tables 1-3) of compounds $\mathbf{1}$ and 5 showed that the structure of 5 should be close to that of $\mathbf{1}$, with the exception of signals assigned to $\mathrm{C}-13$, where an acetoxymethine $\left(\delta_{\mathrm{H}} 5.38,1 \mathrm{H}, \mathrm{s} ; \delta_{\mathrm{C}} 77.1\right)$ in 1 was replaced by a methylene $\left(\delta_{\mathrm{H}} 2.58,1 \mathrm{H}, \mathrm{dd}, J=14.0,5.0 \mathrm{~Hz}, \delta_{\mathrm{H}} 2.25\right.$, $\left.1 \mathrm{H}, \mathrm{dd}, J=14.0,8.0 \mathrm{~Hz} ; \delta_{\mathrm{C}} 44.1\right)$ in $\mathbf{5}$. The planar structure of 5 could be established by analyzing the ${ }^{1} \mathrm{H}-{ }^{1} \mathrm{H}$ COSY and HMBC correlations (Figure 1). The relative stereochemistry of $\mathbf{5}$ was confirmed by analyzing the key NOE correlations (Figure 3), and by comparison of these correlations with those of $\mathbf{1}$. The structure of sarcocrassocolide $\mathbf{J}$, as shown in formula $\mathbf{5}$, was thus established.

Sarcrocrassocolide K (6) was shown by HRESIMS to possess the molecular formula $\mathrm{C}_{20} \mathrm{H}_{28} \mathrm{O}_{4}$ $\left(\mathrm{m} / \mathrm{z} 355.1888[\mathrm{M}+\mathrm{Na}]^{+}\right)$. Comparison of the NMR data (Tables 1 and 3 ) of compounds 5 and $\mathbf{6}$ showed that both compounds have similar structures. Moreover, $\mathrm{H}_{3}-19\left(\delta_{\mathrm{H}} 1.32, \mathrm{~s}\right)$ and $\mathrm{C}-8\left(\delta_{\mathrm{C}} 73.0\right)$ of 6 displayed signals at upper field in comparison with the corresponding signals of $5\left(\delta_{\mathrm{H}} 1.40, \mathrm{H}_{3}-19\right.$; $\delta_{\mathrm{C}} 84.9, \mathrm{C}-8$ ), showing the presence of a hydroxy group at C-8 of $\mathbf{6}$. Furthermore, reduction of 5 with triphenylphosphine was found to give $\mathbf{6}$. Thus, the structure of $\mathbf{6}$ was established.

Sarcrocrassocolide L (7) was shown by HRESIMS to possess the molecular formula $\mathrm{C}_{20} \mathrm{H}_{28} \mathrm{O}_{4}$ $\left(m / z 355.1885[\mathrm{M}+\mathrm{Na}]^{+}\right)$. Comparison of the NMR data (Tables 1 and 3 ) of compounds 6 and 7 showed both compounds could be C-8 epimers. The planar structure of $\mathbf{7}$ was also confirmed by the ${ }^{1} \mathrm{H}-{ }^{1} \mathrm{H}$ COSY and HMBC correlations (Figure 1). The relative configuration of 7 , which should be the C-8 epimer of 6 , was determined by key NOE correlations (Figure 3 ).

Figure 3. Key NOESY correlations for $\mathbf{5}$ and $\mathbf{7}$.

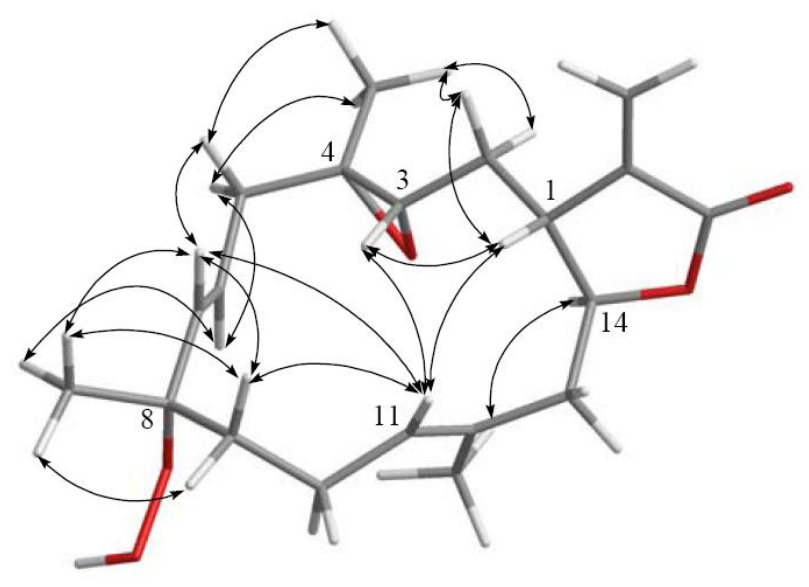

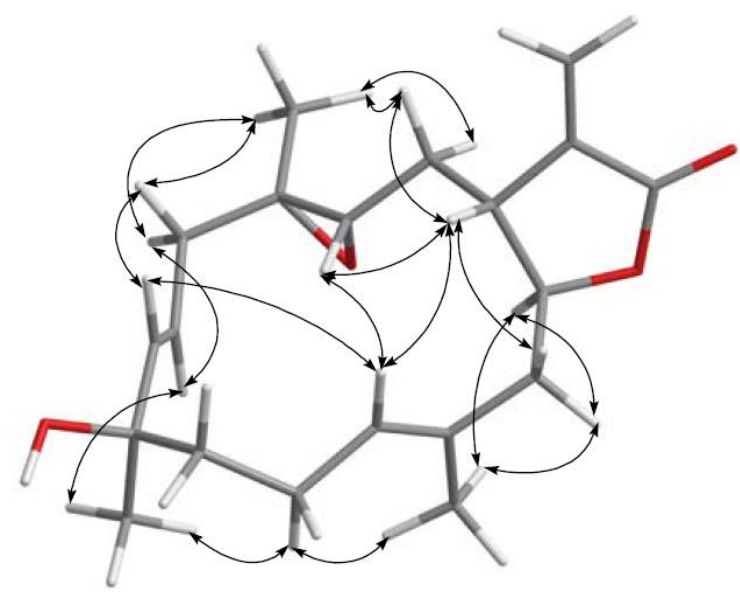


Table 3. ${ }^{1} \mathrm{H}$ NMR data for compounds 5-7.

\begin{tabular}{clll}
\hline \multicolumn{1}{c}{$\mathbf{5}^{\boldsymbol{a}}$} & \multicolumn{1}{c}{$\mathbf{6}^{\boldsymbol{a}}$} & \multicolumn{1}{c}{$\mathbf{7}^{\boldsymbol{a}}$} \\
\hline 1 & $2.80 \mathrm{ddd}(10.5,5.0,3.0)^{c}$ & $2.79 \mathrm{ddd}(10.5,5.5,3.0)$ & $2.84 \mathrm{ddd}(10.5,5.5,2.5)$ \\
2 & $1.83 \mathrm{ddd}(15.5,10.5,5.5)$ & $1.90 \mathrm{~m}$ & $1.83 \mathrm{~m}$ \\
& $1.78 \mathrm{ddd}(15.5,7.0,3.0)$ & $1.75 \mathrm{ddd}(14.5,7.5,3.0)$ & \\
3 & $2.66 \mathrm{dd}(7.0,5.5)$ & $2.71 \mathrm{dd}(7.5,4.5)$ & $2.71 \mathrm{t}(6.0)$ \\
5 & $2.60 \mathrm{dd}(14.0,5.0)$ & $2.58 \mathrm{~m}$ & $2.58 \mathrm{dd}(15.0,6.0)$ \\
& $2.15 \mathrm{dd}(14.0,6.5)$ & $2.15 \mathrm{ddd}(26.0,10.5,3.0)$ & $2.12 \mathrm{dd}(15.0,8.0)$ \\
6 & $5.57 \mathrm{ddd}(16.0,6.5,5.0)$ & $5.53 \mathrm{~m}$ & $5.53 \mathrm{ddd}(16.0,8.0,6.0)$ \\
7 & $5.58 \mathrm{~d}(16.0)$ & $5.55 \mathrm{~d}(16.0)$ & $5.61 \mathrm{~d}(16.0)$ \\
9 & $2.04 \mathrm{~m}$ & $1.91 \mathrm{~m}$ & $1.73 \mathrm{~m}$ \\
& $1.51 \mathrm{~m}$ & $1.57 \mathrm{~m}$ & $2.19 \mathrm{~m}$ \\
10 & $2.34 \mathrm{dt}(13.5,8.0)$ & $2.28 \mathrm{~d}(8.0)$ & $2.09 \mathrm{~m}$ \\
& $2.02 \mathrm{~m}$ & $2.06 \mathrm{~m}$ & $5.29 \mathrm{t}(7.0)$ \\
11 & $5.23 \mathrm{brs}$ & $5.24 \mathrm{t}(6.5)$ & $2.55 \mathrm{dd}(15.0,6.0)$ \\
13 & $2.58 \mathrm{dd}(14.0,5.0)$ & $2.59 \mathrm{dd}(15.0,5.5)$ & $2.35 \mathrm{dd}(15.0,6.0)$ \\
& $2.25 \mathrm{dd}(14.0,8.0)$ & $2.26 \mathrm{~d}(8.0)$ & $4.47 \mathrm{q}(6.0)$ \\
14 & $4.49 \mathrm{dt}(8.0,5.0)$ & $4.47 \mathrm{dt}(8.0,5.5)$ & $6.31 \mathrm{~d}(3.0)$ \\
17 & $6.32 \mathrm{~d}(2.5)$ & $6.33 \mathrm{~d}(2.5)$ & $5.60 \mathrm{brs}$ \\
& $5.62 \mathrm{~d}(2.5)$ & $5.63 \mathrm{~d}(2.5)$ & $1.34 \mathrm{~s}$ \\
18 & $1.32 \mathrm{~s}$ & $1.33 \mathrm{~s}$ & $1.30 \mathrm{~s}$ \\
19 & $1.40 \mathrm{~s}$ & $1.32 \mathrm{~s}$ & $1.65 \mathrm{~s}$ \\
20 & $1.67 \mathrm{~s}$ & $1.67 \mathrm{~s}$ & \\
\hline S-OAc & & &
\end{tabular}

${ }^{a}$ Spectra recorded at $500 \mathrm{MHz}$ in $\mathrm{CDCl}_{3} ;{ }^{b}$ Spectra recorded at $400 \mathrm{MHz}$ in $\mathrm{CDCl}_{3} ;{ }^{c} J$ values $(\mathrm{Hz})$ in parentheses.

It is noteworthy to mention that metabolites 1-7 are cembranoids possessing an $\alpha$-methylene- $\gamma$-lactonic group with a rarely found trans 6,7-disubstituted double bond, which has been discovered previously only in the soft coral Eunicea pinta [4]. These compounds could be the oxidized products of the related 7,8-olefinic analogues, although we have not yet successfully discovered that a cembranoid with the 7,8-double bond was converted into the corresponding 8-hydroxy or 8-hydroperoxy derivative under air in our laboratory. The cytotoxicity of compounds 1-7 against the proliferation of a limited panel of cancer cell lines, including Daoy, HEp-2, MCF-7 and WiDr carcinoma cell lines was evaluated. The results (Table 4) showed that compounds 1-4 were found to exhibit cytotoxicity against all or part of the above carcinoma cell lines, while compound $4\left(\mathrm{ED}_{50}\right.$ values of $5.1 \pm 1.2,5.8 \pm 0.5,8.4 \pm 1.5$ and $6.4 \pm 2.0 \mu \mathrm{M}$ against above carcinoma cell lines, respectively) is the most potent one. Compound $\mathbf{5}$, the 13-deacetoxy derivative of $\mathbf{1}$, with $\mathrm{ED}_{50}$ values of $>20 \mu \mathrm{M}$ against above carcinoma cell lines and compound $\mathbf{7}$, the 13-deacetoxy derivative of 4 , with $\mathrm{ED}_{50}$ values of $>20 \mu \mathrm{M}$ against above carcinoma cell lines, are less cytotoxic than $\mathbf{1}$ and $\mathbf{4}$, respectively; therefore, it was suggested that the acetoxy group of $\mathrm{C}-13$ is important for the cytotoxicity of compounds $\mathbf{1}-\mathbf{7}$. Compound $\mathbf{1}\left(\mathrm{ED}_{50}\right.$ value of $19.4 \pm 2.4 \mu \mathrm{M}$ against MCF-7 cells) which is the 8-peroxidized form of $\mathbf{3}$ ( $\mathrm{ED}_{50}$ values of $9.4 \pm 2.5 \mu \mathrm{M}$

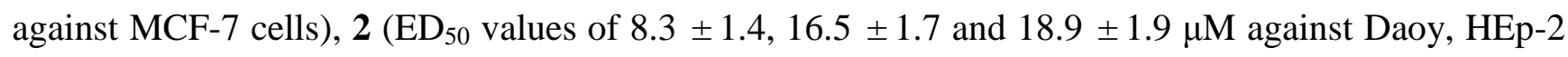
and WiDr cells, respectively) which is the 8-peroxidized form of $\mathbf{4}$, and 5 (ED50 values of $>20 \mu \mathrm{M}$ against Daoy, HEp-2 and WiDr cells) which is the 8-peroxidized form of $\mathbf{6}$, are less cytotoxic than the 
corresponding 8-hydroxy derivatives 3, 4 and 6, respectively; therefore, it was found that the hydroxy group at C-8 could enhance the cytotoxicity of cembranoids 1-7, in comparison with the C-8 hydroperoxy-bearing analogues. In the present study, the in vitro anti-inflammatory effects of compounds 1-7 were also tested by examining the inhibitory activity of these compounds toward the LPS-induced up-regulation of pro-inflammatory proteins, iNOS and COX-2 in RAW264.7 macrophage cells (Figure 4). At a concentration of $10 \mu \mathrm{M}$, compounds 1-7 were found to significantly reduce the levels of iNOS protein, relative to the control cells stimulated with LPS only. Furthermore, at the same concentration, metabolite 4 also could effectively reduce COX-2 expression with LPS treatment. Thus, compounds 1-7 might be useful anti-inflammatory agents, while $\mathbf{4}$ is a promising anti-inflammatory lead compound as $\mathbf{4}$ significantly inhibited the expression of both iNOS and COX-2 proteins. Compared to the biological activities of known cembranoids [9-24], 1-7 have shown satisfactory bioactivities and may warrant further study.

Table 4. Cytotoxicity of compounds 1-7 (ED $50 \mu \mathrm{M})$.

\begin{tabular}{ccccc}
\hline Compound & Daoy & HEp-2 & MCF-7 & WiDr \\
\hline 1 & $7.3 \pm 1.7$ & $15.0 \pm 1.9$ & $19.4 \pm 2.4$ & $18.4 \pm 0.9$ \\
2 & $8.3 \pm 1.4$ & $16.5 \pm 1.7$ & $9.6 \pm 2.7$ & $18.9 \pm 1.9$ \\
3 & $6.4 \pm 2.0$ & $13.5 \pm 2.5$ & $9.4 \pm 2.5$ & $18.7 \pm 1.0$ \\
4 & $5.1 \pm 1.2$ & $5.8 \pm 0.5$ & $8.4 \pm 1.5$ & $6.4 \pm 2.0$ \\
5 & $>20$ & $>20$ & $>20$ & $>20$ \\
6 & $9.9 \pm 4.0$ & $>20$ & $10.2 \pm 1.0$ & $>20$ \\
7 & $>20$ & $>20$ & $>20$ & $>20$ \\
Mitomycin-C & $0.44 \pm 0.06$ & $0.30 \pm 0.06$ & $0.30 \pm 0.12$ & $0.47 \pm 0.12$ \\
\hline
\end{tabular}

Figure 4. Effect of compounds 1-7 on iNOS and COX-2 proteins expression of RAW264.7 macrophage cells by immunoblot analysis: (A) Immunoblots of iNOS and $\beta$-actin; (B) Immunoblots of COX-2 and $\beta$-actin. The values are mean \pm SEM $(n=6)$. Relative intensity of the LPS alone stimulated group was taken as $100 \%$ ** Significantly different from LPS alone stimulated group $(* P<0.05) .{ }^{a}$ stimulated with LPS, ${ }^{b}$ stimulated with LPS in the presence of 1-7 $(10 \mu \mathrm{M})$.
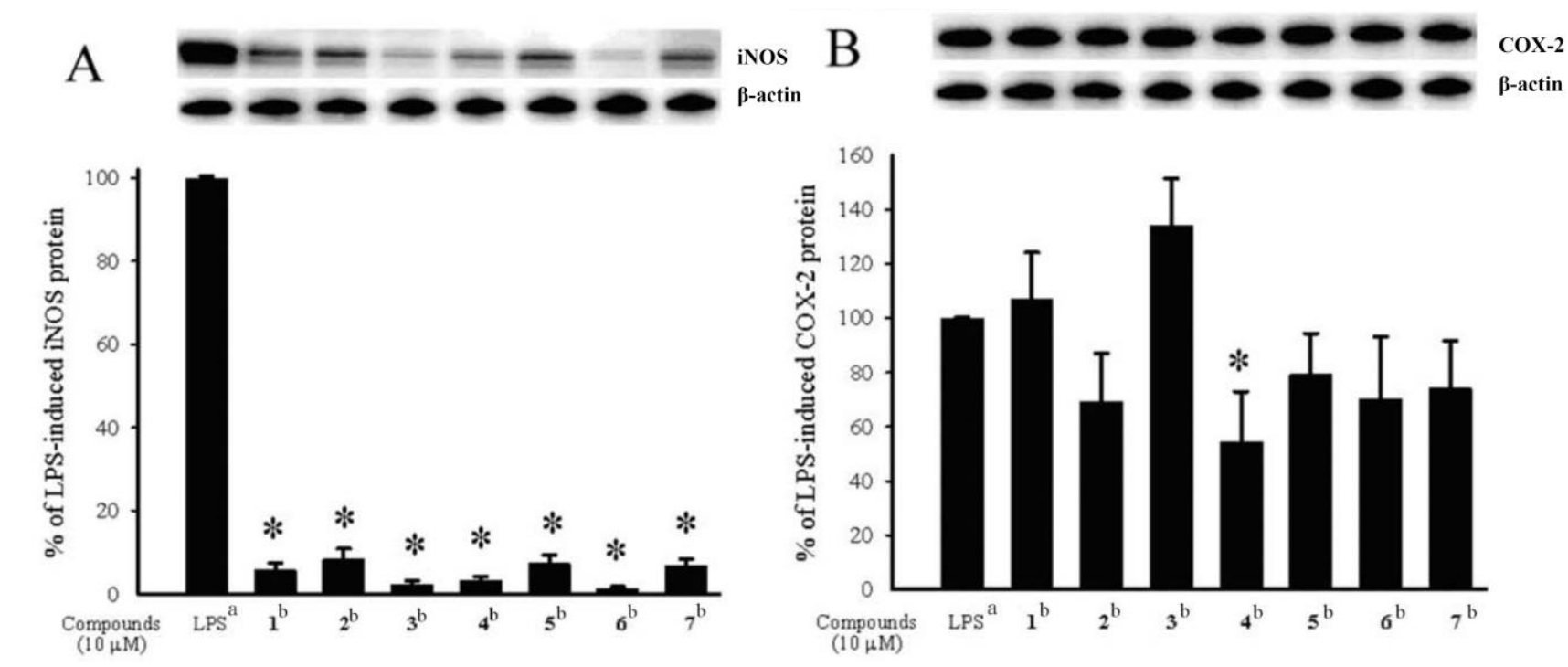


\section{Experimental Section}

\subsection{General Experimental Procedures}

Melting points were determined using a Fisher-Johns melting point apparatus. Optical rotations were measured on a JASCO P-1020 polarimeter. Ultraviolet spectra were recorded on a JASCO V-650 spectrophotometer. IR spectra were recorded on a JASCO FT/IR-4100 infrared spectrophotometer. The NMR spectra were recorded on a Varian 400MR FT-NMR (or Varian Unity INOVA500 FT-NMR) instrument at $400 \mathrm{MHz}$ (or $500 \mathrm{MHz}$ ) for ${ }^{1} \mathrm{H}$ and $100 \mathrm{MHz}$ (or $125 \mathrm{MHz}$ ) for ${ }^{13} \mathrm{C}_{\text {in }} \mathrm{CDCl}_{3}$. LRMS and HRMS were obtained by ESI on a Bruker APEX II mass spectrometer. Silica gel (Merck, 230-400 mesh) was used for column chromatography. Precoated silica gel plates (Merck, Kieselgel 60 F-254, $0.2 \mathrm{~mm}$ ) were used for analytical TLC. High-performance liquid chromatography was performed on a Hitachi L-7100 HPLC apparatus with a Merck Hibar Si-60 column $(250 \times 21 \mathrm{~mm}$, $7 \mu \mathrm{m})$ and on a Hitachi L-2455 HPLC apparatus with a Supelco C18 column $(250 \times 21.2 \mathrm{~mm}, 5 \mu \mathrm{m})$.

\subsection{Animal Material}

S. crassocaule (specimen no. 20070402), taxonomically identified by Prof. Chang-Feng Dai of National Taiwan University, was collected by hand using scuba off the coast of Dongsha, Taiwan, in April 2007, at a depth of 5-10 m, and stored in a freezer until extraction. A voucher sample was deposited at the Department of Marine Biotechnology and Resources, National Sun Yat-sen University.

\subsection{Extraction and Separation}

The frozen bodies of $S$. crassocaule $(0.5 \mathrm{~kg}$, wet wt) were minced and exhaustively extracted with EtOAc $(1 \mathrm{~L} \times 5)$. The EtOAc extract $(7.3 \mathrm{~g})$ was chromatographed over silica gel by column chromatography and eluted with EtOAc in $n$-hexane (0-100\%, stepwise), then with acetone in EtOAc (50-100\%, stepwise) to yield 28 fractions. Fraction 17, eluting with $n$-hexane-EtOAc (1:1), was further purified over silica gel using $n$-hexane-acetone (3:1) to afford seven subfractions (C1-C7). Subfraction C5 was purified by reverse-phase HPLC using $\mathrm{MeOH}-\mathrm{H}_{2} \mathrm{O}$ (3:2) to afford 5 (2.2 mg). Subfraction C7 was separated by reverse-phase HPLC using $\mathrm{MeOH}-\mathrm{H}_{2} \mathrm{O}$ (7:5) to afford 1 (6.3 mg) and 2 (9.3 mg). Fraction 18, eluting with $n$-hexane-EtOAc (1:1), and was further purified over silica gel using $n$-hexane-Acetone (3:1) to afford seven subfractions (D1-D7). Subfraction D3 was separated by reverse-phase HPLC using $\mathrm{MeOH}-\mathrm{H}_{2} \mathrm{O}(3: 2)$ to afford 6 (3.7 mg) and 7 (2.6 mg). Fraction 19, eluting with $n$-hexane-EtOAc (1:2), and was further purified over silica gel using $n$-hexane-Acetone $(2: 1)$ to afford seven subfractions (E1-E7). Subfraction E5 was separated by reverse-phase HPLC using $\mathrm{MeOH}-\mathrm{H}_{2} \mathrm{O}(3: 2)$ to afford $3(5.2 \mathrm{mg})$ and 4 (4.3 $\left.\mathrm{mg}\right)$.

Sarcocrassocolide F (1): white solid; mp 92.0-95.0 ${ }^{\circ} \mathrm{C} ;[\alpha]^{25}{ }_{\mathrm{D}}-42\left(c 0.6, \mathrm{CHCl}_{3}\right)$; IR (neat) $v_{\max } 3403$, 3014, 2974, 2933, 1757, 1659, 1430, 1371, 1273 and $1228 \mathrm{~cm}^{-1}$; UV (MeOH) $\lambda_{\max } 213(\log \varepsilon=3.8)$; ${ }^{13} \mathrm{C}$ and ${ }^{1} \mathrm{H}$ NMR data, see Tables 1 and 2; ESIMS $\mathrm{m} / \mathrm{z} 429[\mathrm{M}+\mathrm{Na}]^{+}$; HRESIMS $\mathrm{m} / z$ 429.1887 $[\mathrm{M}+\mathrm{Na}]^{+}$(calcd for $\mathrm{C}_{22} \mathrm{H}_{30} \mathrm{O}_{7} \mathrm{Na}, 429.1889$ ).

Sarcocrassocolide G (2): colorless oil; $[\alpha]^{25}-56$ (c 0.6, $\mathrm{CHCl}_{3}$ ); IR (neat) $v_{\max } 3420,2969,2931$, 2859, 1758, 1714, 1659, 1431, 1372, 1273 and $1229 \mathrm{~cm}^{-1}$; UV (MeOH) $\lambda_{\max } 209(\log \varepsilon=3.7) ;{ }^{13} \mathrm{C}$ and 
${ }^{1} \mathrm{H}$ NMR data, see Tables 1 and 2; ${ }^{1} \mathrm{H}$ NMR (Pyridine- $\left.d_{5}, 500 \mathrm{MHz}\right) \delta 3.38(1 \mathrm{H}, \mathrm{dt}, J=11.5,3.0 \mathrm{~Hz}$, H-1), 1.94 (1H, m, H-2a), 1.82 (1H, m, H-2b), $2.81(1 \mathrm{H}, \mathrm{t}, J=6.0 \mathrm{~Hz}, \mathrm{H}-3), 2.51$ (1H, dd, $J=14.5$, $7.0 \mathrm{~Hz}, 5 \mathrm{a}), 2.33(1 \mathrm{H}, \mathrm{dd}, J=14.5,7.0 \mathrm{~Hz}, 5 \mathrm{~b}), 5.63(1 \mathrm{H}, \mathrm{dt}, J=16.0,7.0 \mathrm{~Hz}, \mathrm{H}-6), 5.89(1 \mathrm{H}, \mathrm{d}$, $J=16.0 \mathrm{~Hz}, \mathrm{H}-7), 2.06(1 \mathrm{H}, \mathrm{ddd}, J=10.0,5.0,3.5 \mathrm{~Hz}, \mathrm{H}-9 \mathrm{a}), 1.97(1 \mathrm{H}, \mathrm{dt}, J=13.5,5.0 \mathrm{~Hz}, \mathrm{H}-9 \mathrm{~b})$, $2.22\left(2 \mathrm{H}, \mathrm{m}, \mathrm{H}_{2}-10\right), 5.66(1 \mathrm{H}, \mathrm{brs}), 5.81(1 \mathrm{H}, \mathrm{s}), 4.91(1 \mathrm{H}, \mathrm{t}, J=3.0 \mathrm{~Hz}, \mathrm{H}-14), 6.45(1 \mathrm{H}, \mathrm{d}, J=2.5 \mathrm{~Hz}$, H-17a), 5.76 (1H, d, J=2.5 Hz, H-17b), 1.30 (3H, s, H $\left.3^{-18}\right), 1.55\left(1 \mathrm{H}, \mathrm{s}, \mathrm{H}_{3}-19\right), 1.80\left(1 \mathrm{H}, \mathrm{s}, \mathrm{H}_{3}-20\right)$, $2.03(3 \mathrm{H}, \mathrm{s}, 13-\mathrm{OAc}), 13.04(1 \mathrm{H}, \mathrm{s}, 8-\mathrm{OOH}) ;{ }^{13} \mathrm{C}$ NMR (Pyridine- $\left.d_{5}, 125 \mathrm{MHz}\right) \delta 38.7(\mathrm{CH}, \mathrm{C}-1)$, $35.7\left(\mathrm{CH}_{2}, \mathrm{C}-2\right), 59.3(\mathrm{CH}, \mathrm{C}-3), 59.8$ (qC, C-4), $39.6\left(\mathrm{CH}_{2}, \mathrm{C}-5\right), 124.6(\mathrm{CH}, \mathrm{C}-6), 139.2(\mathrm{CH}, \mathrm{C}-7)$, 84.7 (qC, C-8), $37.9\left(\mathrm{CH}_{2}, \mathrm{C}-9\right), 22.4\left(\mathrm{CH}_{2}, \mathrm{C}-10\right), 130.0(\mathrm{CH}, \mathrm{C}-11), 130.2$ (qC, C-12), $78.1(\mathrm{CH}, \mathrm{C}-13)$, 82.6 (CH, C-14), 140.7 (qC, C-15), 169.9 (qC, C-16), $122.4\left(\mathrm{CH}_{2}, \mathrm{C}-17\right), 18.7\left(\mathrm{CH}_{3}, \mathrm{C}-18\right), 22.4\left(\mathrm{CH}_{3}\right.$, C-19), $15.5\left(\mathrm{CH}_{3}, \mathrm{C}-20\right), 21.0\left(\mathrm{CH}_{3}, \mathrm{C}-\mathrm{OAc}\right), 170.2$ (qC, C-OAc); ESIMS m/z $429[\mathrm{M}+\mathrm{Na}]^{+}$; HRESIMS $m / z$, 429.1886 [M + Na $]^{+}$(calcd for $\mathrm{C}_{22} \mathrm{H}_{30} \mathrm{O}_{7} \mathrm{Na}, 429.1889$ ).

Sarcocrassocolide H (3): colorless oil; $[\alpha]^{25}-17\left(c 0.5, \mathrm{CHCl}_{3}\right)$; IR (neat) $v_{\max } 3479,2966,2927$, 2856, 1758, 1659, 1432, 1370, 1273 and $1228 \mathrm{~cm}^{-1}$; UV $(\mathrm{MeOH}) \lambda_{\max } 214(\log \varepsilon=3.8) ;{ }^{13} \mathrm{C}$ and ${ }^{1} \mathrm{H}$ NMR data, see Tables 1 and 2; ESIMS $m / z 413[\mathrm{M}+\mathrm{Na}]^{+}$; HRESIMS $m / z 413.1937[\mathrm{M}+\mathrm{Na}]^{+}$ (calcd for $\mathrm{C}_{22} \mathrm{H}_{30} \mathrm{O}_{6} \mathrm{Na}, 413.1940$ ).

Sarcocrassocolide I (4): colorless oil; $[\alpha]^{25}-29\left(c 0.4, \mathrm{CHCl}_{3}\right)$; IR (neat) $v_{\max } 3479,2964,2926$, 2855, 1758, 1658, 1433, 1371, 1273 and $1230 \mathrm{~cm}^{-1}$; UV $(\mathrm{MeOH}) \lambda_{\max } 212(\log \varepsilon=3.7) ;{ }^{13} \mathrm{C}$ and ${ }^{1} \mathrm{H}$ NMR data, see Tables 1 and 2; ESIMS $m / z, 413\left[\mathrm{M}+\mathrm{Na}^{+}\right.$; HRESIMS $m / z 413.1938[\mathrm{M}+\mathrm{Na}]^{+}$ (calcd for $\mathrm{C}_{22} \mathrm{H}_{30} \mathrm{O}_{6} \mathrm{Na}, 413.1940$ ).

Sarcocrassocolide J (5): colorless oil; $[\alpha]^{25}{ }_{\mathrm{D}}-142\left(c\right.$ 0.1, $\mathrm{CHCl}_{3}$ ); IR (neat) $v_{\max } 3382,2961,2928$, 2857, 1760, 1659, 1431, 1384, 1268 and $1231 \mathrm{~cm}^{-1}$; UV $(\mathrm{MeOH}) \lambda_{\max } 213(\log \varepsilon=3.8) ;{ }^{13} \mathrm{C}$ and ${ }^{1} \mathrm{H}$ NMR data, see Tables 1 and 3; ESIMS m/z $371[\mathrm{M}+\mathrm{Na}]^{+}$; HRESIMS $m / z 371.1837[\mathrm{M}+\mathrm{Na}]^{+}$ (calcd for $\mathrm{C}_{20} \mathrm{H}_{28} \mathrm{O}_{5} \mathrm{Na}, 371.1834$ ).

Sarcocrassocolide K (6): colorless oil; $[\alpha]^{25}-51$ (c 0.3, $\mathrm{CHCl}_{3}$ ); IR (neat) $v_{\max } 3471,2965,2925$, 2856, 1759, 1659, 1384 and $1266 \mathrm{~cm}^{-1}$; UV (MeOH) $\lambda_{\max } 208(\log \varepsilon=3.7) ;{ }^{13} \mathrm{C}$ and ${ }^{1} \mathrm{H}$ NMR data, see Tables 1 and 3; ESIMS $m / z 355[\mathrm{M}+\mathrm{Na}]^{+}$; HRESIMS $m / z 355.1888\left[\mathrm{M}+\mathrm{Na}^{+}\right.$(calcd for $\left.\mathrm{C}_{20} \mathrm{H}_{28} \mathrm{O}_{4} \mathrm{Na}, 355.1885\right)$.

Sarcocrassocolide L (7): white solid; $\mathrm{mp} 85-87^{\circ} \mathrm{C}$; $[\alpha]^{25}{ }_{\mathrm{D}}-140\left(c 0.2, \mathrm{CHCl}_{3}\right)$; IR (neat) $v_{\max } 3445$, 2965, 2925, 2854, 1759, 1654, 1455, 1374 and $1267 \mathrm{~cm}^{-1}$; UV (MeOH) $\lambda_{\max } 208(\log \varepsilon=3.6) ;{ }^{13} \mathrm{C}$ and ${ }^{1} \mathrm{H}$ NMR data, see Tables 1 and 3; ESIMS $m / z 355[\mathrm{M}+\mathrm{Na}]^{+} ; \operatorname{HRESIMS~} m / z 355.1883[\mathrm{M}+\mathrm{Na}]^{+}$ (calcd for $\mathrm{C}_{20} \mathrm{H}_{28} \mathrm{O}_{4} \mathrm{Na}, 355.1885$ ).

Reduction of sarcocrassocolide F (1). A solution of $\mathbf{1}(1.0 \mathrm{mg})$ in diethyl ether $(3 \mathrm{~mL})$ was added excess amount triphenylphosphine and the mixture was stirred at room temperature for $4 \mathrm{~h}$. The solution was concentrated under reduced pressure to afford a residue which was subjected to reversed-phase HPLC with $\mathrm{MeOH}-\mathrm{H}_{2} \mathrm{O}(3: 2)$ to yield $3(0.8 \mathrm{mg}, 83 \%)$.

Reduction of sarcocrassocolide $\mathrm{G}(\mathbf{2})$. By using the same reaction and purification procedures as the reduction of $\mathbf{1}$, the solution of $\mathbf{2}(1.0 \mathrm{mg})$ was converted to $\mathbf{4}(0.7 \mathrm{mg})$ in $73 \%$ yield. 
Reduction of sarcocrassocolide $\mathbf{J}(\mathbf{5})$. By using the same reaction and purification procedures as the reduction of $\mathbf{1}$, the solution of $\mathbf{5}(0.5 \mathrm{mg})$ was converted to $\mathbf{6}(0.4 \mathrm{mg})$ in $84 \%$ yield.

\subsection{Cytotoxicity Testing}

Cell lines were purchased from the American Type Culture Collection (ATCC). Cytotoxicity assays of compounds 1-7 were performed using the MTT [3-(4,5-dimethylthiazol-2-yl)-2,5-diphenyltetrazolium bromide] colorimetric method [25,26].

\subsection{In Vitro Anti-Inflammatory Assay}

Macrophage (RAW264.7) cell line was purchased from ATCC. In vitro anti-inflammatory activities of compounds 1-7 were measured by examining the inhibition of lipopolysaccharide (LPS) induced upregulation of iNOS (inducible nitric oxide synthetase) and COX-2 (cyclooxygenase-2) proteins in macrophages cells using western blotting analysis [27,28].

\section{Acknowledgements}

This work was supported by grants from the Ministry of Education (98C031702) and National Science Council of Taiwan (NSC 98-2113-M-110-002-MY3) awarded to J.-H. Sheu.

\section{References}

1. Bishara, A.; Rudi, A.; Benayahu, Y.; Kashman, Y. Three biscembranoids and their monomeric counterpart cembranoid, a biogenetic diels-alder precursor, from the soft coral Sarcophyton elegans. J. Nat. Prod. 2007, 70, 1951-1954.

2. Bensemhoun, J.; Rudi, A.; Bombarda, I.; Gaydou, E.M.; Kashman, Y.; Aknin, M. Flexusines A and B and epimukulol from the soft coral Sarcophyton flexuosum. J. Nat. Prod. 2008, 71, 1262-1264.

3. Marrero, J.; Benítez, J.; Rodríguez, A.D.; Zhao, H.; Raptis, R.G. Bipinnatins K-Q, Minor cembrane-type diterpenes from the west Indian gorgonian Pseudopterogorgia kallos: Isolation, structure assignment, and evaluation of biological activities. J. Nat. Prod. 2008, 71, 381-389.

4. Shi, Y.-P.; Rodríguez, A.D.; Barnes, C.L.; Sánchez, J.A.; Raptis, R.G.; Baran, P. New terpenoid constituents from Eunicea pinta. J. Nat. Prod. 2002, 65, 1232-1241.

5. Rashid, M.A.; Gustafson, K.R.; Boyd, M.R. HIV-inhibitory cembrane derivatives from a Philippines collection of the soft coral Lobophytum species. J. Nat. Prod. 2000, 63, 531-533.

6. König, G.M.; Wright, A.D. New cembranoid diterpenes from the soft coral Sarcophyton ehrenbergi. J. Nat. Prod. 1998, 61, 494-496.

7. Iwashima, M.; Matsumoto, Y.; Takahashi, H.; Iguchi, K. New marine cembrane-type diterpenoids from the Okinawan soft coral Clavularia koellikeri. J. Nat. Prod. 2000, 63, 1647-1652.

8. Iguchi, K.; Fukaya, T.; Takahashi, H.; Watanabe, K. Stolonilactone, a novel terpenoid-related compound, isolated from the Okinawan soft coral Clavularia koellikeri. J. Org. Chem. 2004, 69, 4351-4355. 
9. Su, J.-H.; Ahmed, A.F.; Sung, P.-J.; Chao, C.-H.; Kuo, Y.-H.; Sheu, J.-H. Manaarenolides A-I, new diterpenoids from the soft coral Sinularia manaarensis. J. Nat. Prod. 2006, 69, 1134-1139.

10. Lu, Y.; Huang, C.-Y.; Lin, Y.-F.; Wen, Z.-H.; Su, J.-H.; Kuo, Y.-H.; Chiang, M.Y.; Sheu, J.-H. Anti-inflammatory cembranoids from the soft corals Sinularia querciformis and Sinularia granosa. J. Nat. Prod. 2008, 71, 1754-1759.

11. Ahmed, A.F.; Tai, S.-H.; Wen, Z.-H.; Su, J.-H.; Wu, Y.-C.; Hu, W.-P.; Sheu, J.-H. A C-3 methylated isocembranoid and 10-oxocembranoids from a Formosan soft coral Sinularia grandilobata. J. Nat. Prod. 2008, 71, 946-951.

12. Ahmed, A.F.; Wen, Z.-H.; Su, J.-H.; Hsieh Y.-T.; Wu, Y.-C.; Hu, W.-P.; Sheu, J.-H. Oxygenated cembranoids from a Formosan soft coral Sinularia gibberosa. J. Nat. Prod. 2008, 71, 179-185.

13. Su, J.-H.; Lin, Y.-F.; Lu, Y.; Huang, C.-Y.; Wang, W.-H.; Fang, T.-Y.; Sheu, J.-H. Oxygenated cembranoids from the cultured and wild-type soft corals Sinularia flexibilis. Chem. Pharm. Bull. 2009, 57, 1189-1192.

14. Lu, Y.; Su, J.-H.; Hsieh, C.-H.; Liu, Y.-C.; Kuo, Y.-H.; Wen, Z.-H.; Hsu, C.-H.; Sheu, J.-H. Cembranoids from the soft corals Sinularia granosa and Sinularia querciformis. Chem. Pharm. Bull. 2010, 58, 464-466.

15. Chen, B.-W.; Chao, C.-H.; Su, J.-H.; Huang, C.-Y.; Dai, C.-F.; Wen, Z.-H.; Sheu, J.-H. A novel symmetric sulfur-containing biscembranoid from the Formosan soft coral Sinularia flexibilis. Tetrahedron Lett. 2010, 44, 5764-5766.

16. Cheng, S.-Y.; Wen, Z.-H.; Wang, S.-K.; Chiou, S.-F.; Hsu, C.-H.; Dai, C.-F.; Chiang, M.Y.; Duh, C.-Y. Unprecedented hemiketal cembranolides with anti-inflammatory activity from the soft coral Lobophytum durum. J. Nat. Prod. 2009, 72, 152-155.

17. Chao, C.-H.; Wen, Z.-H; Wu, Y.-C.; Yeh, H.-C.; Sheu, J.-H. Cytotoxic and anti-inflammatory cembranoids from the soft coral Lobophytum crassum. J. Nat. Prod. 2008, 71, 1819-1824.

18. Huang, H.-C.; Ahmed, A.F.; Su, J.-H.; Wu, Y.-C.; Chiang, M.Y.; Sheu, J.-H. Crassocolides A-F, new cembranoids with a trans-fused lactone from the soft coral Sarcophyton crassocaule. J. Nat. Prod. 2006, 69, 1554-1559.

19. Huang, H.-C.; Chao, C.-H.; Kuo, Y.-H.; Sheu, J.-H. Crassocolides G-M, cembranoids from a Formosan soft coral Sarcophyton crassocaule. Chem. Biodivers. 2009, 6, 1232-1242.

20. Cheng, Y.-B.; Shen, Y.-C.; Kuo, Y.-H.; Khalil, A.T. Cembrane diterpenoids from the Taiwanese soft coral Sarcophyton stolidotum. J. Nat. Prod. 2008, 71, 1141-1145.

21. Cheng, S.-Y.; Wang, S.-K.; Chiou, S.-F.; Hsu, C.-H.; Dai, C.-F.; Chiang, M.Y.; Duh, C.-Y. Cembranoids from the octocoral Sarcophyton ehrenbergi. J. Nat. Prod. 2010, 73, 197-203.

22. Sheu, J.-H.; Wang, G.-H.; Sung, P.-J.; Duh, C.-Y.; Chiang, M.Y. Pachyclavulariolides G-L and secopachyclavulariaenone A, seven novel diterpenoids from the soft coral Pachycalvularia violacea. Tetrahedron 2001, 57, 7639-7648.

23. Sheu, J.-H.; Wang, G.-H.; Duh, C.-Y.; Soong, K. Pachyclavulariolides M-R, six novel diterpenoids from a Taiwanese soft coral Pachyclavularia violacea. J. Nat. Prod. 2003, 66, 662-666.

24. Lin, W.-Y.; Su, J.-H.; Lu, Y.; Wen, Z.-H.; Dai, C.-F.; Kuo, Y.-H.; Sheu, J.-H. Cytotoxic and Anti-inflammatory cembranoids from the Dongsha Atoll soft coral Sarcophyton crassocaule. Bioorg. Med. Chem. 2010, 18, 1936-1941. 
25. Alley, M.C.; Scudiero, D.A.; Monks, A.; Hursey, M.L.; Czerwinski, M.J.; Fine, D.L.; Abbott, B.J.; Mayo, J.G.; Shoemaker, R.H.; Boyd, M.R. Feasibility of drug screening with panels of human tumor cell lines using a microculture tetrazolium assay. Cancer Res. 1988, 48, 589-601.

26. Scudiero, D.A.; Shoemaker, R.H.; Paull, K.D.; Monks, A.; Tierney, S.; Nofziger, T.H.; Currens, M.J.; Seniff, D.; Boyd, M.R. Evaluation of a soluble tetrazolium/formazan assay for cell growth and drug sensitivity in culture using human and other tumor cell lines. Cancer Res. 1988, $48,4827-4833$.

27. Jean, Y.-H.; Chen, W.-F.; Sung, C.-S.; Duh, C.-Y.; Huang, S.-Y.; Lin, C.-S.; Tai, M.-H.; Tzeng, S.-F.; Wen, Z.-H. Capnellene, a natural marine compound derived from soft coral, attenuates chronic constriction injury-induced neuropathic pain in rats. Br. J. Pharmacol. 2009, $158,713-725$.

28. Jean, Y.-H.; Chen, W.-F.; Duh, C.-Y.; Huang, S.-Y.; Hsu, C.-H.; Lin, C.-S.; Sung, C.-S.; Chen, I.-M.; Wen, Z.-H. Inducible nitric oxide synthase and cyclooxygenase-2 participate in anti-inflammatory and analgesic effects of the natural marine compound lemnalol from Formosan soft coral Lemnalia cervicorni. Eur. J. Pharmacol. 2008, 578, 323-331.

Samples Availability: Not available.

(C) 2011 by the authors; licensee MDPI, Basel, Switzerland. This article is an open access article distributed under the terms and conditions of the Creative Commons Attribution license (http://creativecommons.org/licenses/by/3.0/). 